\title{
SISTEM PAKAR UNTUK MENDIAGNOSA PENYAKIT LEUKEMIA DENGAN METODE BACKWARD CHAINING
}

\author{
Nofriadiman $^{1}$, Elmawati $^{2}$, Rima Fitri Yeni $^{3}$ \\ 1,2,3 Program Studi Sistem Informasi \\ Sekolah Tinggi Teknologi Industri (STTIND) Padang \\ Email : nofriadiman@yahoo.co.id,elmawati_si@yahoo.co.id
}

\begin{abstract}
Leukemia or blood cancer today is not detected early and the cause can not be in the unknown. The cost of examination and specialists who are sometimes not in place resulted in a lack of motivation of people to check early, when the cancer early checks can be dealt with quickly. To overcome this they invented an expert system that is created using the programming language Java, which can help experts in dealing with the diagnosis of leukemia using the method of inference Backward Chaining. The results of this design is a leukemia expert system applications, where users can check the program or examination and received the diagnosis of the disease suffered by the user program.
\end{abstract}

Keywords : Expert System, Leukemia

\section{PENDAHULUAN}

Komputer merupakan salah satu produk dari perkembangan teknologi informatika yang berfungsi sebagai alat bantu untuk menyelesaikan berbagai pekerjaan manusia. Disamping sebagai alat bantu, komputer juga menyimpan data, memperbaiki data serta mengambilkan informasi yang diinginkan, dimana data dan informasi tersebut tersimpan didalam media penyimpanan.

Seiring perkembangan teknologi, dikembangkan pula suatu teknologi yang mampu mengadopsi proses dan cara berfikir manusia yaitu teknologi Artificial Intelligence atau kecerdasan buatan. Sistem pakar adalah salah satu bagian dari Kecerdasan Buatan yang mengandung pengetahuan dan pengalaman yang dimasukkan oleh satu atau banyak pakar ke dalam satu area pengetahuan tertentu sehingga setiap orang dapat menggunakannya untuk memecahkan berbagai masalah yang bersifat spesifik, dalam hal ini adalah permasalahan diagnosa gejala leukemia.

Perkembangan leukemia atau kanker darah sekarang ini belum dapat dideteksi secara dini dan penyebabnya belum bisa di diketahui. Penyakit ini merupakan kanker yang mematikan dan belum bisa dicegah dan cara penyembuhannya pun masih menjadi bahan perdebatan. Leukemia berasal dari bahasa yunani yaitu Leukos-Putih dan Haima-
Darah yang merupakan suatu penyakit yang ditandai dengan proliferasi dini yang berlebihan dari sel darah putih.Leukemia merupakan keganasan yang sering dijumpai tetapi hanya merupakan sebagian kecil dari kangker secara keseluruhan. Leukemia biasanya terjadi pada orang-orang paruh usia atau orang lebih tua, meskipun ia juga dapat terjadi pada anak-anak. Pada stadium pertama dari Leukemia kebanyakan orang tidak mempunyai gejala-gejala kanker. Ketika gejala-gejala timbul, seperti : terlihat pucat selama 3 hari, merasa letih, kepala pusing, lebam di tangan dan kaki, bengkak kemerahan sejak 1 minggu yang lalu yang muncul disekitar dagu, leher dan dada, yang berisi nanah dan pecah mengeluarkan darah bercampur nanah, dan masih banyak lagi.

Melihat perkembangan zaman yang semakin maju, dimana komputer dapat membantu mengerjakan pekerjaan manusia sehari-hari, komputer juga bisa menggantikan seorang pakar untuk mendiagnosa suatu penyakit apabila seorang pakar tersebut sedang tidak berada ditempat, pindah tugas, pensiun, atau pakar tersebut sudah meninggal dunia.

Oleh karena itu dibangun suatu sistem pakar yang dapat membantu para pakar dalam menangani masalah diagnosa penyakit leukemia menggunakan metode inferensi Backward Chaining. 
Berdasarkan latar belakang masalah, maka penulis dapat mengidentifikasi masalah sebagai berikut :

1. Dokter Ahli atau Pakar yang terkadang tidak berada ditempat karena urusan tertentu, pindah tugas, pensiun atau meninggal dunia

2. Besarnya biaya pemeriksaan penyakit leukemia

Berdasarkan identifikasi masalah, maka dapat dirumuskan permasalahan sebagai berikut :

1. Bagaimana merancang sistem pakar untuk diagnosa penyakit leukemia ?

2. Bagaimana penggunaan metode Backward Chaining untuk pengambilan keputusan sistem pakar?

3. Bagaimana kinerja sistem pakar menggunakan metode Backward Chaining?

Penelitian ini bertujuan untuk membangun sebuah sistem berbasis pengetahuan kedokteran dalam mendiagnosa penyakit leukemia yang dapat ditampilkan dalam program java sehingga mempermudahnya mendiagnosa penyakit leukemia dan membantu mengembangkan sistem komputer sebagai alat bantu dalam ilmu kesehatan.

Penelitian ini diharapkan dapat memberikan manfaat sebagai berikut :

1. Bagi Penulisan

Dapat menerapkan secara langsung teoriteori yang didapat selama kuliah di Sekolah Tinggi Teknologi Industri (STTIND) Padang.

2. Bagi Pakar

Hasil penelitian ini diharapakan dapat membantu pakar untuk mendiagnosa penyakit Leukemia pada pasien apabila pakar tersebut tidak berada ditempat.

3. Bagi Masyarakat dan Pasien

Hasil penelitian ini dapat menjadi suatu sarana untuk membantu masyarakat dalam mengetahui penyakit leukemia.

\section{METODELOGI PENELITIAN}

\subsection{Jenis Penelitian}

Jenis penelitian yang peneliti lakukan adalah penelitian Terapan (Applied Research).Penelitian terapan adalah penelitian yang hati-hati, sistematis dan terus-menerus terhadap suatu masalah dengan tujuan digunakan segera untuk keperluan tertentu.
Hasil penelitian tidak perlu sebagai suatu penemuan baru, tetapi merupakan aplikasi baru dari peneliti yang telah ada.

\subsection{Lokasi Penelitian}

Penelitian dilakukan di RSUD Dr. M.Zein Painan Kabupaten Pesisir Selatan Sumatera Barat. Pemilihan tempat dilakukan secara purposif (sengaja) dengan pertimbangan akan kelengkapan data dan informasi yang diperlukan untuk kegiatan penelitian mengenai analisis gejala-gejala leukemia. Sedangkan waktu penelitian pada bulan November 2015.

\subsection{Variabel Penelitian}

Variabel penelitian merupakan suatu atribut dari sekelompok objek yang diteliti yang mempunyai variasi satu dengan yang lain dalam kelompok tersebut. Sesuai dengan permasalahan yang diteliti maka variable penelitian meliputi kegiatan pencarian informasi tentang gejala-gejala leukemia.

\subsection{Metode Penelitian}

Didalam melakukan penelitian ini, metode-metode yang penulis lakukan adalah sebagai berikut :

1. Penelitian pustaka merupakan kegiatan untuk mencari informasi yang berhubungan dengan teori, maupun untuk perancangan program aplikasi yang di pakai.

2. Penelitian laboratorium merupakan kegiatan merancang, menulis dan mencoba program aplikasi yang akan digunakan.

3. Penelitian lapangan merupakan kegiatan melihat langsung kelokasi dan pengambilan data-data untuk di olah di dalam database.

4. Perancangan sistem meliputi perancangan sistem pakar dan perancangan penyususnan rule-rule dan konklusi.

5. Data-data penunjang yang diperlukan dari berbagai tempat dan forum dalam bentuk kesimpulan, fakta-fakta dan aturan datang yang saling berhubungan disimpan kedalam MySQL sebagai tempat penyimpanan data.

\subsection{Data dan Sumber Data}

1. Data yang dibutuhkan

Data-data yang penulis butuhkan dalam penelitian ini ada 2 yaitu : 
a. Data Primer

data primer adalah data yang didapat langsung di lapangan yaitu pada RSUD Dr. M.Zein Painan.

b. Data Sekunder

Data Sekunder diperoleh dari bukubuku, jurnal dan $e$-book.

2. Sumber Data

Sumber data yang peneliti dapatkan berasal dari pendataan dan wawancara langsung pada pakar leukemia yang ada di RSUD Dr. M. Zein Painan.

\subsection{Kerangka Metodologi}

Untuk memperjelas arah penelitian ini, dapat dilihat pada gambar kerangka metodologi berikut ini :

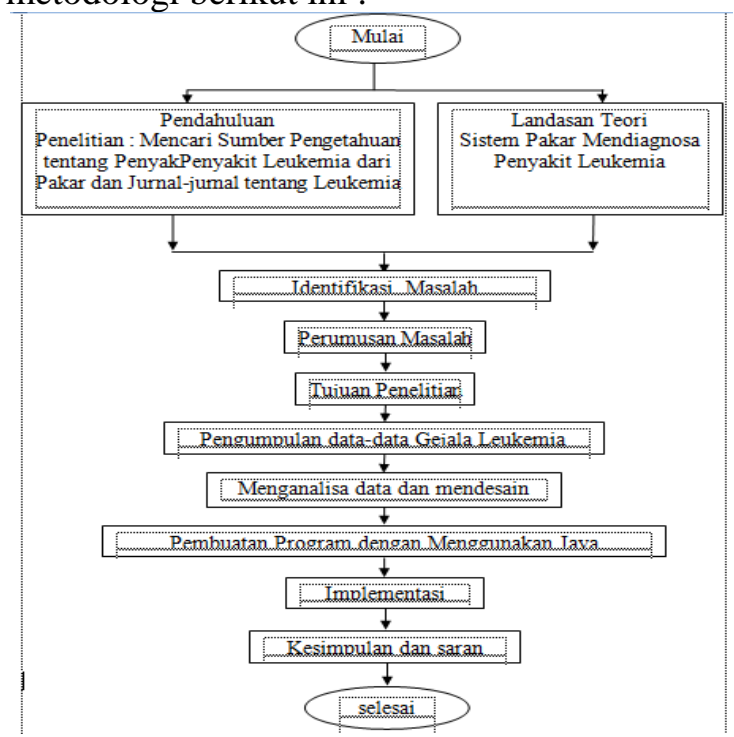

Gambar 3.1 Kerangka Metodologi Penelitian

Penelitianini diawali dengan melakukan observasi serta studi literatur tentang penyakit Leukemia, kemudian dilanjutkan dengan mengidentifikasi masalah yang ada dan merumuskannya. Kemudian setelah itu dilakukan penetapan tujuan penelitian yang ingin dicapai dan pengumpulan data-data penunjang penelitian ini. Data yang telah dikumpulkan akan dianalisa dan didesain sebuahsistem yang akan diimplementasikan,kemuadian akan mendapat kesimpulan serta saran.

\section{ANALISA DAN PERANCANGAN 3.1 Analisa Sistem}

Analisa kebutuhan merupakan langkah pertama untuk menentukan perbuatan sistem seperti apa yang akan dihasilkan. Perangkat lunak yang baik dan sesuai dengan kebutuhan pengguna, dan pengguna sangat tergantung pada keberhasilan dalam melakukan analisa kebutuhan.

Pada sistem pakar yang mendiagnosa penyakit leukemia, dengan pembuatan sebuah basis pengetahuan. Pengetahuannya yang berasal dari pakar tersebut dipresentasikan ke dalam bentuk-bentuk satuan pengetahuan.

Proses inferensi yang digunakan pada deteksi kerusakan pada sistem kemudi adalah pelacakan mundur (Backward Chaining). Proses penalaran dimulai dari kesimpulan kemudian merunut mundur ke gejala-gejala dari penyakit leukemia tersebut. Dalam penalaran ini aturan rule (rule) akan diuji melalui penalarannya dari sekumpulan data yang mendukung hipotesa tersebut menuju kesimpulan. Penalaran mundur (Backward Chaining) dimulai dengan user menentukan tujuan dari penyakit yang ditemukan dari sistem struktur tersebut user dapat mellihat gejala-gejala yang ditemukan. Kemudian user dapat menentukan saran dari permasalahan yang dihadapi pada diagnosa penyakit leukemia.

\subsection{Perancangan Sistem Pakar}

Adapun desain pada sistem pakar adalah mendiagnosa faktor-faktor yang perlu diperhatikan untuk setiap penyakit leukemia sehingga dapat memberikan saran. Pada bab ini juga diuraikan analisis dan desain sistem pakar, yang meliputi:desain sistem, penyajian fakta-fakta dan aturan, algoritma pencarian diagnosa fakta-fakta yang perlu diperhatikan untuk setiap penyakit leukemia serta desain antar muka pemakai.

\subsection{Desain Arsitektur Sistem}

Design sistem pada program sistem pakar dalam mendiagnosa penyakit leukemia gejalagejala penyakit tersebut. Bahasan ini terdiri dari struktur menu, desain form login, desain form menu pemakai, desain form penelusuran macam-macam penyakit leukemia tersebut.

Perancangan perangkat lunak sistem pakar dalam diagnosa penyakit leukemia berdasarkan penyakit leukemia mempunyai lima komponen utama. Yaitu:Knowledge berisi aturan-aturan macam-macam penyakit leukemia dan gejala-gejala yang harus ditimbulkan pada penyakit leukemia. Sedangkan basis data sistem pakar dibutuhkan untuk memahami, meluruskan dan menyelesaikan masalah, basis data mempunyai tabel macam-macam penyakit 
leukemia, tabel gejala, tabel uraian, tabel kerja dan tabel user. Inference engine merupakan perangkat lunak yang melakukan penalaran dengan menggunakan pengetahuan yang ada seperti prosedur-prosedur untuk mencocokkan fakta berupa penyakit dan gejala, yaitu kode penyakit dan kode gejala.

User inference adalah perangkat lunak yang menyediakan media komunikasi antar pengguna dengan sistem, seperti prosedur untuk membaca masukan dari pemakai yaitu macam-macam penyakit leukemia dan gejalagejala yang harus ditimbulkan, prosedur penampilan hasil diagnosa penyakit leukemia, prosedur untuk menghasilkan keluaran dalam bentuk hard copy, form penelusuran. Explanation facilities/fasilitas penjelasan merupakan komponen tambahan yang dibuat agar pemakai dapat memanfaatkan sistem dengan benar.

User adalah pemakai yang menggunakan program sistem pakar ini untuk mengetahui diagnosa penyakit leukemia berdasarkan macam-macam penyakit dan gejala-gejala yang harus diperhatikan pada setiap penyakit.

Desain arsitektur sistem pakar dalam diagnosa penyakit leukemia berdasarkan macam-macam penyakit leukemia dan gejalagejala yang harus diperhatikan pada setiap penyakit, gejala yang harus diperhatikan dan uraian dari setiap penyakit telah ditentukan oleh pakar di bidang kesehatan berdasarkan literatur bukunya dan dapat dilihat pada gambar 4.1 dibawah ini.

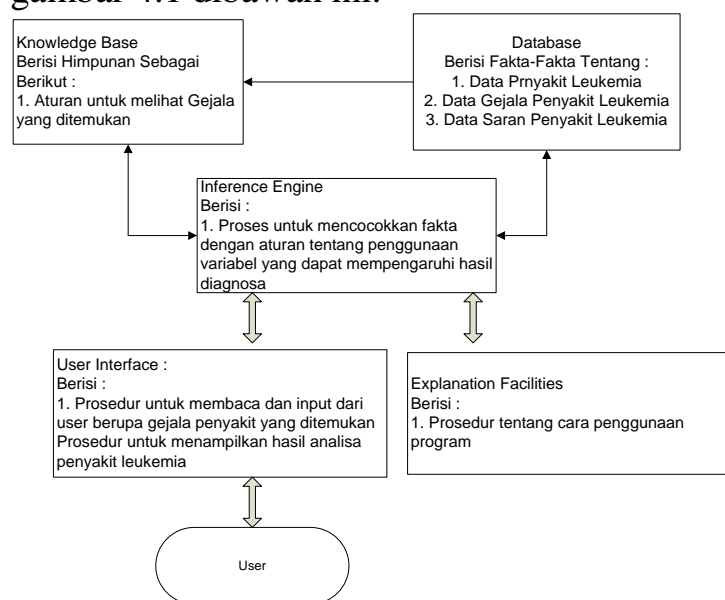

Gambar 4.1. Desain Arsitektur Sistem Pakar

\section{Desain Global}

Prosedur perancangan sistem sacara umum untuk pembangunan sistem pakar untuk penyakit leukemia memberikan gambaran kepada user tentang sistem yang akan dirancang dan informasi apa saja yang akan dihasilkan dari sistem yang telah dikembangkan.

Pada perancangan ini sangat dibutuhkan UML (Unified Modelling Language) yang dapat membantu user untuk mengoperasikan sistem, $U M L$ bisa berfungsi sebagai jembatan dalam mengkomunikasikan beberapa aspek dari sistem.

Berikut adalah gambar secara umum $U M L$ :

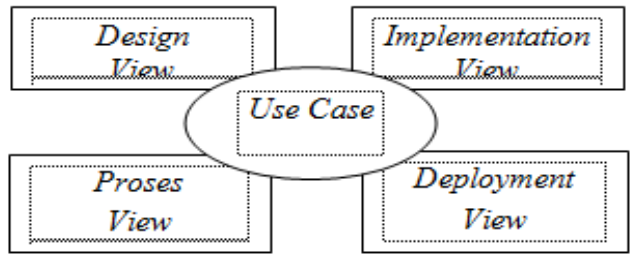

Gambar 4.2 Model 4+1 View

\section{Use Case Diagram}

Use Diagram menggambarkan fungsionalitas yang diharapkan dari sebuah sistem. Yang ditekankan adalah "apa" yang diperbuat sistem, dan bukan "bagaimana". Sebuah use case merepresentasikan sebuah interaksi antara faktor dengan sistem.

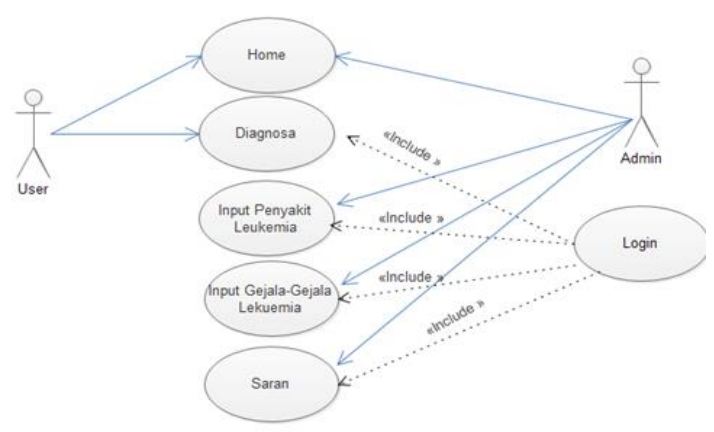

Gambar 4.3 Use Case Diagram

Use case diagram diatas memodelkan prilaku (behavior) dari sistem pada aplikasi java Desktop.

Dalam diagram ini terdapat dua actor yaitu pasien (user) dan Pakar serta tujuh use case yaitu :Login, Home, Diagnosa, Input Penyakit Leukemia, Input Gejala Leukemia, Saran

\subsection{Perancangan Basis Pengetahuan (Knowledge Base)}

Untuk mendukung penalaran diagnosis penyakit leukemia, maka pengetahuan yang diperoleh dari pakar dapat dipresentasikan 
dalam bentuk pohon keputusan yang dapat dilihat ada Gambar 4.4

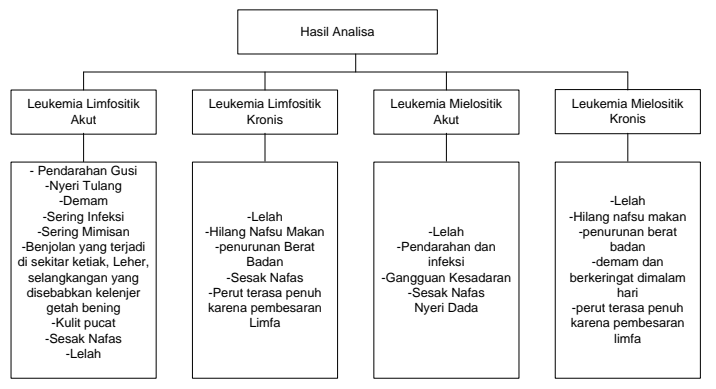

Gambar 4.4 Pohon Keputusan

Pada penalaran berbasis pengetahuan penyelesaian masalah dapat diselesaikan secara berurutan dimana teknik yang digunakan adalah backward chaining yaitu dengan melakukan penelusuran dari rule pertama sampai rule terakhir. Adapun fakta yang memprediksi diagnosa penyakit leukemia berdasarkan penyakit leukemia dan gejala-gejala yang harus diperhatikan pada setiap penyakit :

1. Data penyakit leukemia

Setelah dilakukan analisa data pada perancangan sistem ini telah diperoleh 4 data penyakit leukemia yang paling sering terjadi, dan bila pada proses selanjutnya ditemukan penyakit leukemia yang baru, maka admin bisa menginputkan data baru diberi nomor urut otomatis, disini digunakan kode "P1" untuk urutan pertama, "P2" untuk urutan kedua, "P3" untuk urutan ketiga, "P4" untuk urutan ke empat,

\section{Data gejala-gejala penyakit}

Dari data-data penyakit leukemia diatas diperoleh gejala-gejala yang dimungkinkan menyebabkan penyakit-penyakit tersebut. Disinigejala-gejalatersebutbelum diklasifikasikan menurut jenis penyakit tertentu. Untuk identifikasi gejala-gejala tersebut dalam sistem digunakan kode "G1" untuk urutan pertama, "G2" untuk urutan kedua dan seterusnya.

\section{Cara Representasi Pengetahuan}

Representasi pengetahuan merupakan metode yang digunakan untuk mengodekan pengetahuan dalam sebuah sistem pakar yang berbasispengetahuan.Pengkodean

dimaksudkan untuk menangkap sifat-sifat penting problema dan membuat ingformasi untuk dapat diakses oleh prosedur pemecahan proplema. Representasi pengetahuan yang digunakan dalam sistem pakar dalam mendiagnosa penyakit

\section{Rule Sistem Pakar}

Rule Sistem pakar merupakan aturan diagnosa sistem pakar yang digunakan untuk menyusun aturan-aturan yang akan dirancang untuk membuat suatu keputusan, rule sistem pakar untuk mendiagnosa penyakit leukemia dapat dilihat pada gambar 4.5.

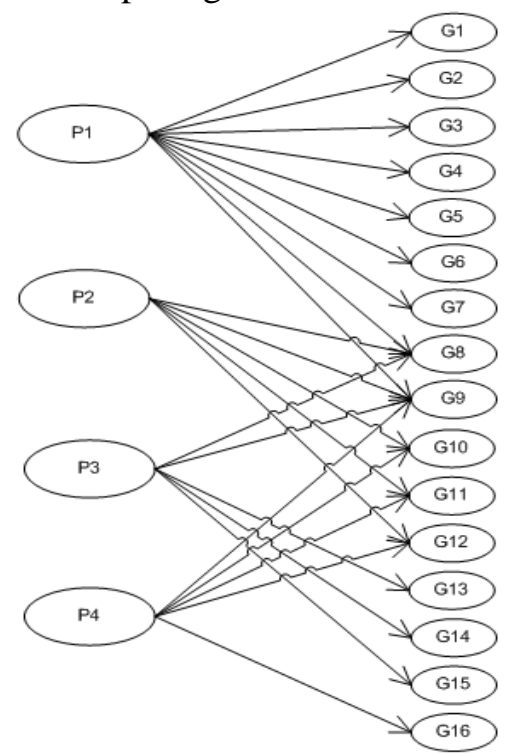

Gambar 4.5 Rule Sistem Pakar

Gambar diatas adalah rule manual sistem pakar untuk mendiagnosa penyakit Leukemia, dimana nama macam-macam penyakit disimbolkan dengan $\mathrm{P} 1, \mathrm{P} 2, \mathrm{P} 3$ dan $\mathrm{P} 4$ yang dapat dilihat pada Tabel 4.2 Tabel Penyakit. Dan gejala gejala penyakit leukemia disimbolkan dengan G1, G2, G3, G4, G5, G6, G7, G8, G9, G10, G11, G12, G13, G14, G15 dan G16 yang dapat dilihat pada Tabel 4.3 Data Gejala-gejala Penyakit Leukemia.

Dimana P1 mempunyai gejala-gejala G1, G2, G3, G4, G5, G6, G7, G8, dan G9, P2 mempunyai gejala-gejala G8, G9, G10, G11 dan G12, P3 mempunyai gejala-gejala G8, G9, G13, G14 dan G15, dan P4 mempunyai gejala-gejala G9, G10, G11, G12 dan G16 yang dapat dilihat pada Tabel 41 Data Macam-macam Penyakit dan Gejala pada Diagnosa Leukemia.

\subsection{Mesin Inferensi}

Mesin inferensi adalah bagian dari sistem pakar yang melakukan penalaran dengan menggunakan isi daftar aturan berdasarkan urutan dan pola tertentu selama proses konsultasi mesin inferensi menggunakan strategi backward chaining. Dimana 
penelusuran akan dimulai dari penyakit, gejala-gejala dan saran yang direkomendasi. Backward chaining digunkan untuk menguji fakta-fakta yang dijawab pengguna dengan aturan yang telah disimpan dalam sistem satu demi satu hingga dapat diambil satu kesimpulan dan menentukan fakta-fakta yang akan ditanyakan kepada pengguna.

\subsection{Database}

Sebelum melakukan perancangan tabel yang akan dibuat, maka terlebih dahulu dilakukan perancangan untuk penentuan basis data, pada rancangan ini akan memperlihatkan hubungan atau relasi antara beberapa entitas yang akan digunakan. Entity Relational Diagram (ERD) dari entity-entity dibawah ini akan diimplementasikan ke dalam tabel-tabel beserta relasi yang digunakan dapat dilihat pada gambar 4.6.

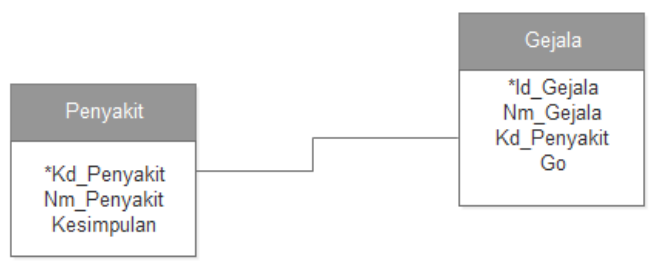

Gambar 4.6 Entity Relationship Diagram (ERD)

\subsection{Proses perancangan sistem}

Membutuhkan suatu database yang digunakan untuk menyimpan data dan informasi yang diperlukan dalam sistem. Database berisi tentang fakta-fakta yang dibutuhkan pemakai yaitu berupa data-data variabel dari : tabel penyakit leukemia, tabel gejala-gejalatabelsaran yang harus diperhatikan. Tabel-tabel yang digunakan untuk menjelaskan masing-masing tabel pada sistem pakar.

\section{User Interface (Perancangan Antar Muka)}

Perancangan antarmuka pada penelitian ini menjelaskan rutinitas program yang akan dijalankan oleh sebuah sistem komputer untuk menjelaskan interaksi antara pemakai dengan sistem yang dibuat.

Pada sub bab ini akan digambarkan rancangan antarmuka (interface) menggunakan form tampilan yang dilengkapi tombol pada menu yang disertai dengan beberapa pilihan dan hasil rancangan ini akan dinamakan sebagai expert system. Rancangan menu adalah membuat menu-menu yang akandigunakan dalam aplikasi sistem pakar. Adapun rancangan struktural antarmuka yang dibuat adalah sebagai berikut :

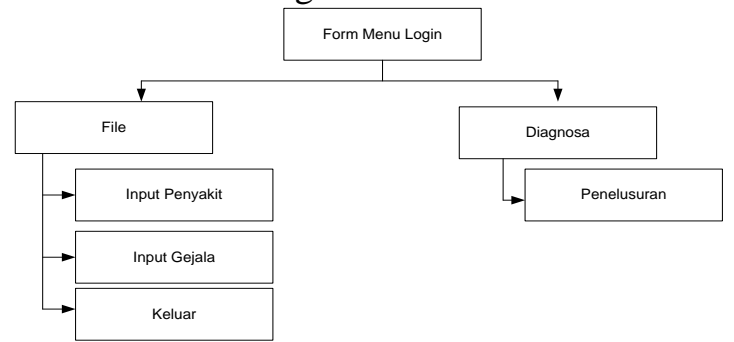

Gambar 4.7 Perancangan Interface Sistem

Didalam Form Menu Login terdapat dua bagian yaitu File dan Diagnosa, didalam File tersebut terdapat Form Input Penyakit, Input Gejala dan Keluar yang hanya bisa digunakan pakar. Sedangkan pada diagnosa hanya terdapat satu Form Penelusuran yang dapat digunakan oleh User atau pengguna program sistem pakar untuk mendiagnosa penyakit leukemia.

\subsection{Desain Rancangan Program}

Rancangan Form untuk memudahkan dalam memberikan Gambaran program berdasarkan rancangan.

\subsubsection{Desain Form Login}

Pada rancangan form desain login berisi status user 2 buah yaitu pemakai biasa dan pakar. Pada pemakai bisa tidak menggunaka password yang hanya bisa untuk menggunakan sistem, sedangkan bagi pakar yang menggunakan password dapat melakukan penambahan, mengedit rule.Menu login dapat dilihat pada Gambar 4.8

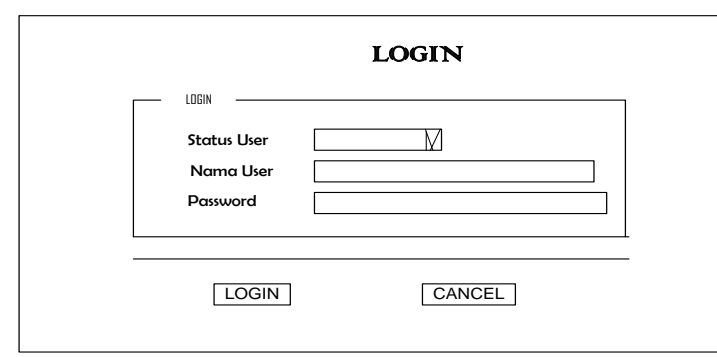

Gambar 4.8 Desain Form Login

\subsubsection{Desain Form Menu Utama}

Desain form menu utama ini terdiri dari sub menu File, Diagnosadimana sub menu tersebut masing-masing mempunyai sub menu lainnya. Desain form menu utama dapat dilihat pada Gambar 4.9. 


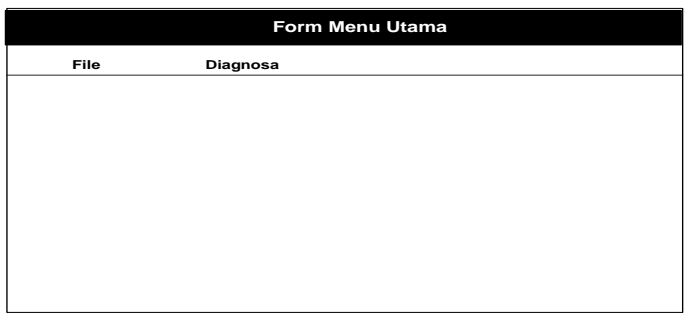

Gambar 4.9 Desain Menu Utama

\subsubsection{Desain Form Input Penyakit}

Desain formPenyakit dapat diinput data Kd_Penyakit, Nm_Penyakit dan kesimpulan. Desain form input penyakit dapat dilihat pada Gambar 4.10.

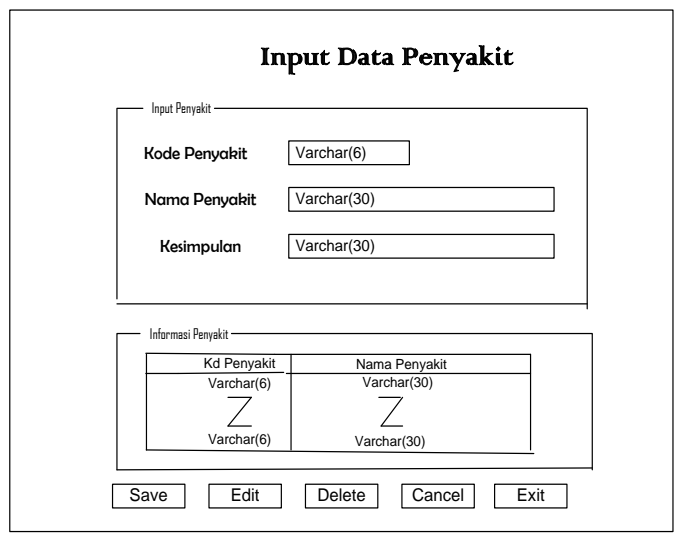

Gambar 4.10 Desain Input Form Penyakit

\subsubsection{Desain Form Input Gejala-Gejala}

Desain form pertumbuhan dapat diinput Id_Penyakit, Nm_Penyakit, desain form input fakta-fakta yang memperngaruhi dapat dilihat pada gambar 4.11.

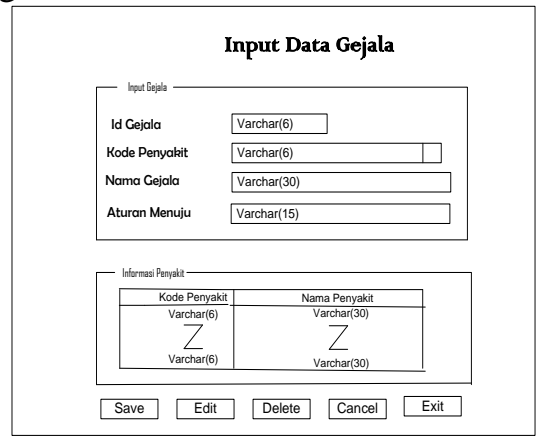

Gambar 4.11. Desain Input Data Gejala

\subsubsection{Desain Form Diagnosa Penyakit}

Pada desain form diagnosa dan penelusuran terdiri dari gejala-gejala segingga muncul hasil diagnosa. Desain form diagnosa penyakit leukemia dilihat pada Gambar 4.12

\section{DIAGNOSA PENYAKIT LEUKEMIA \\ NAMA PASIEN : \\ Apakah Anda Mengalami ...? \\ Anda Terkena :}

Gambar 4.12 Desain Form Diagnosa Penyakit Leukemia

Pada form di atas user harus mengisi nama pasien untuk menganalisa penyakit leukemia. Kemudian muncul pertanyaan yang harus dijawab oleh user sehingga didapatkan hasil dari pertanyaan yang telah dijawab untuk mendapatkan saran.

\section{TESTING DAN IMPLEMENTASI \\ 4.1 Implementasi Sistem}

Tahapan awal di pembuatan program ini dimulai dari menentukan data-data yang diperlukan dalam pembuatan program, seperti data-data penyakit leukemia, gejala-gejala yang ditimbulkan dan diagnosa.

Setelah semua data yang diperlukan sudah jelas barulah dirancang databasenya dengan menggunakan MySQL. Pemilihan software ini didasarkan atas beberapa hal diantaranya, mudah digunakan karena mempunyai fitur yang telah familiar. Perancangan database disesuaikan dengan struktur tabel serta relasi tabel yang telah diuraikan pada bab sebelumnya.

Setelah merancang database, selanjutnya dirancang antar muka (interface) sistem, yaitu form-form yang dibutuhkan didalam pembuatan program dengan menggunakan Bahasa Pemograman Java Netbeans 7.1.1. Form-form yang dirancang dilengkapi dengan tombol-tombol operasi (Save, Delete, Edit, Cancel dan Exit). Beberapa form dilengkapi dengan dataGrid untuk menanpilkan data-data yang sudah tersimpan di dalam database.

Program yang sudah dirancang dilengkapi dengan manajemen hak akses untuk 2 kategori pengguna, yaitu tingkat admin atau pakar dan tingkat pengguna biasa. Hal ini diterapkan untuk keamanan sistem jika seandainya sistem ini nantinya diletakkan ditempat umum yang mudah diakses oleh orang banyak. 


\subsection{Skenario Sistem}

Skenario sistem menjelaskan bagaimana sistem dijalankan oleh pakar dan pengguna umum. Pakar masuk ke sistem harus login terlebihndahulu untuk melakukan penambahan, edit dan delete database. Skenario pakar login menjelaskan cara pakar agar bisa menjalankan ke sistem, untuk pakar masuk ke sistem maka pakar harus mengisi username dan mengisi password, jika username atau password tidak di isi salah satu maka sistem akan menvalidasi form dan mengeluarkan pesan, jika username yang tidak diisi pesan akan tampil "Username belum diisi", jika password yang tidak diisi pesan akan tampil "Password belum diisi". Jika username dan password telah diisi sistem akan mengecek ke database apakah username dan password ada atau tidak dalam database, jika username atau password tidak ada dalam database maka sistem akan mengeluarkan pesan "Username dan Password Salah". Jika username pakar dan password ada dalam database maka admin dapat masuk ke sistem untuk mengedit, menambah, delete database.

Pada login pengguna umum siapapun boleh masuk untuk menggunakan sistem. Pengguna umum hanya bisa membaca, memilih pilihan yang ada di sistem. Pengguna umum tidak bisa merubah sistem yang telah ada.

Setelah user melakukan login, maka selanjutnya user memilih penyakit yang diinginkan dan memilih gejala-gejala yang ada pada setiap penyakit. Kemudian dari pemilihan dari gejala dan penyakit tersebut didapatkan uraian bagaimana melakukan diagnosa yang nantinya akan menghasilkan saran dari setiap penyakit.

\subsection{Spesifikasi Perangkat Keras dan Perangkat Lunak}

Dalam penerapan dan implementasi dari sitem pakar untuk mendiagnosa penyakit Leukemia mempunyai spesifikasi sebagai berikut :

\subsubsection{Perangkat Keras}

Faktor utama yang paling mendukung dalam implementasi sistem adalah faktor manusia (brainware) selaku sumber daya yang berperan penting dalam mengelola dan mengimplementasikan sistem yang telah dibuat. Selain itu sistem tidak akan dapat bekerja dan berjalan sebagaimana yang diharapkan kalau tidak adanya faktor pendukung seperti perangkat keras (hardware) dan perangkat lunak (software).Hardware adalah seluruh komponen-komponen peralatan yang membentuk suatu sistem komputer, dan peralatan lainnya yang memungkinkan komputer dapat melaksanakan tugasnya.

Perangkat keras yang digunakan untuk membuat dan menjalankan sistem ini adalah sebuah laptop dengan spesifikasi : Processor Intel Pentium Core i3, RAM 2 GB, Monitor 14", Harddisk 320 GB

\subsubsection{Perangkat Lunak}

Perangkat lunak yang digunakan untuk membuat dan menjalankan sistem ini adalah :

1. Sistem Operasi Microsoft Windows 7

2. NetBeans

3. Perangkat lunak pengolah database dengan $M y S Q L$

4. Perangkat lunak aplikasi pengolah kata Microsoft Word 2007

\subsection{Desain Antar Muka (Interface)}

Untuk memudahkan pengoperasian sistem ini, maka rancangan antar muka dibagi atas beberapa jenis, yang disesuaikan dengan fungsinya masing-masing yaitu:

\subsubsection{Form Menu Login}

Pada sistem pakar mendiagnosa penyakit leukemia terdapat dua lingkungan, yaitu lingkungan pengguna dan lingkungan pakar. Jika user masuk menggunakan lingkungan pengguna umum maka tidak dibutuhkan password tapi pengguna umum dibatasi hak aksesnya dalam menggunakan program sistem pakar, pengguna umum hanya bisa menggunakan menu diagnosa, fungsi dari menu diagnosa adalah mendiagnosa penyakit leukemia. Apabila pengguna sistem adalah pakar atau administrator maka untuk memasuki menu login maka harus mengisi password. Fasilitas yang ditawarkan pada menu diagnosa adalah input data-data master yaitu penyakit dan gejala yang ditimbulkan. Tampilan form login dapat dilihat pada Gambar 5.1.

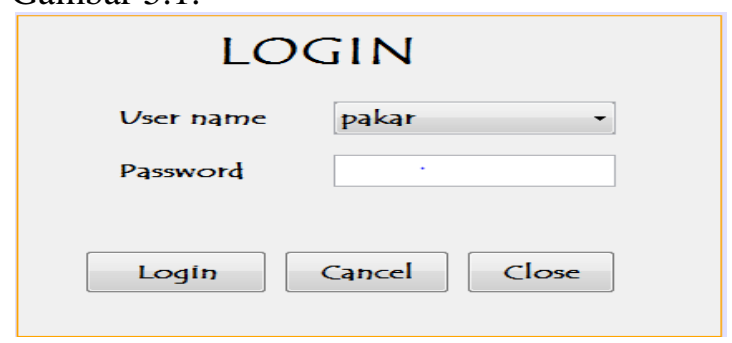

Gambar 5.1. Form Login 


\subsubsection{Form Menu Utama}

Menu pilihan yang ada didalam menu pakar terdiri dari menu pakar, menu diagnosa, menu help.

Masing-masing fungsi dari menu ini adalah :

1. Pada manu pakar akan mengolah datadata penyakit dan gejala-gejala yang ditimbulkan untuk mendiagnosa penyakit leukemia, maka digunakan menu diagnosa yang terdiri dari input yang berisi form inputpenyakit, input data gejala-gejala yang ditimbulkan.

2. Menu diagnosa yaitu menu yang berisi tentang diagnosa penyakit Leukemia .

3. Menu help adalah menu yang digunakan untuk memberikan bantuan atau keterangan program kepada user. Tampilan menu utama ini dapat dilihat pada Gambar 5.2.

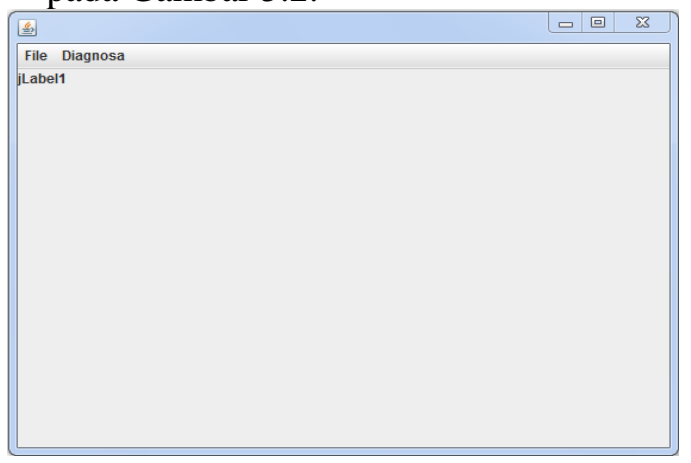

Gambar 5.2 Menu Utama

\subsubsection{Form Input Penyakit}

FormInput adalah form untuk menginput data penyakit leukemia, data penyakit leukemia ada 4 jenis. Jika pakar membutuhkan penambahan data penyakit leukemia bisa diinputkan di form input penyakit leukemia. Forminput data penyakit leukemia dapat dilihat pada Gambar 5.3.

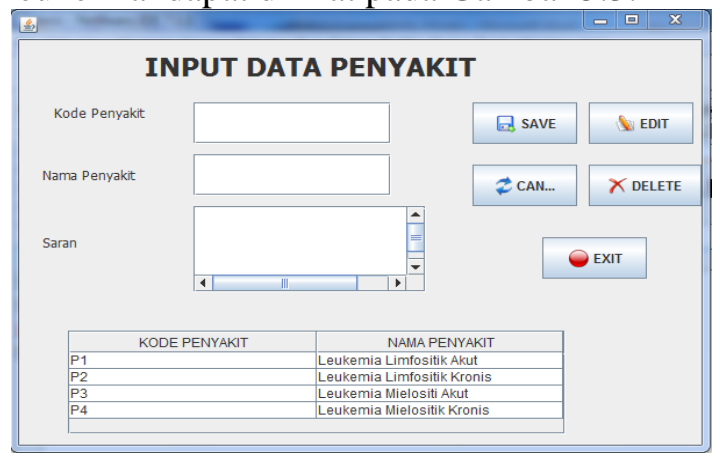

Gambar 5.3 Input Data Penyakit

\subsubsection{Form Input Gejala}

Form untuk menginput gejala-gejala yang harus diperhatikan pada tiap penyakit leukemia, setiap penyakit mempunyai gejalagejala yang harus diperhatikan. Desain input data gejala dapat dilihat pada gambar 5.4

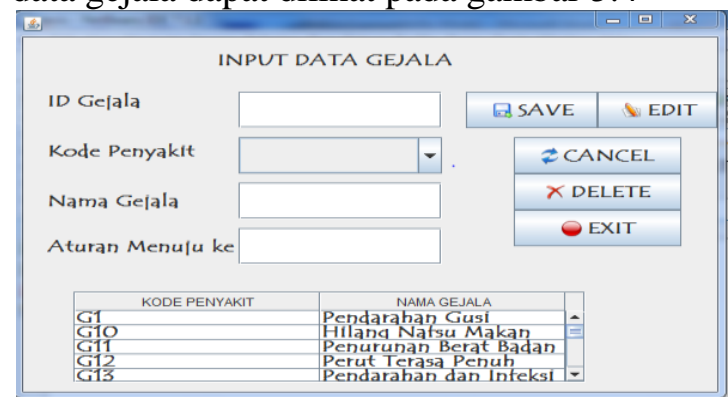

Gambar 5.4 Input Data Gejala

\subsubsection{Form Diagnosa Penyakit Leukemia}

Form diagnosa merupakan form inti untuk pengolahan data untuk menghasilkan sebuah diagnosa. Langkah pertama untuk mengimplementasikan Form Diagnosa ini adalah dengan memasukkan nama pasien yang akan dianalisa, kemudian akan tampil pertanyaan satu persatu, dan dibawah pertanyaan terdapat 2 option button untuk menentukan pilihan Ya atau Tidak. Jika tombol iya atau tidak sudah dipilih dengan cara mengkilikkan dengan otomatis pertanyaan ke dua akan muncul.Tombol hasil digunakan untuk menampilkan kesimpulan diagnosa terakhir dari sistem setelah semua pertanyaan dijawab.

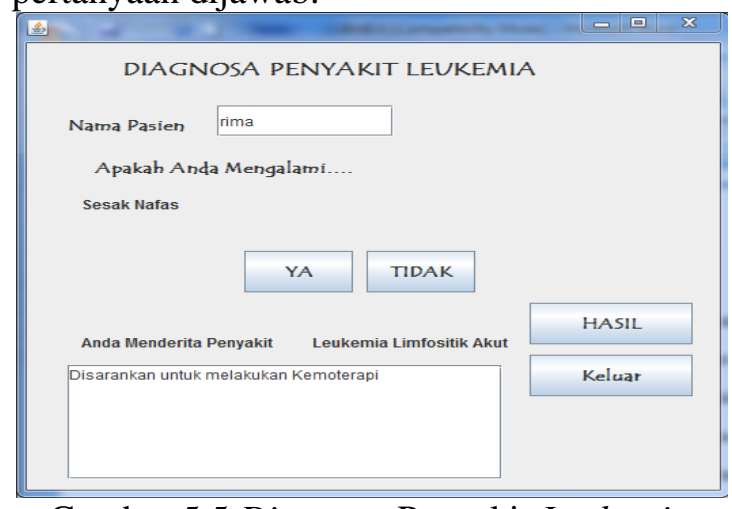

Gambar 5.5 Diagnosa Penyakit Leukemia

\subsection{Analisa Hasil Pengujian}

Hasil dari analisa dignosa penyakit leukemia terhadap penyakit ini menghasilkan sebuah informasi tentang penyakit leukemia yang telah dianalisa dengan menjawab beberapa pertanyaan yang muncul di form diagnosa, seperti contoh pada gambar 5.4 Ibu Intan telah menjawab semua pertanyaan yang sesuai dengan keadaan pasien, maka dapat dilihat hasil analisa diagnosa penyakit Leukemia menghasilkan Ibu Intan menderita 
penyakit Leukemia Limfositik Akut disarankan untuk melakukan Kemoterapi.

\section{KESIMPULAN}

Kesimpulan yang dapat diambil dari pembuatan sistem pakar untuk mendiagnosa penyakit leukemia dengan metode backward chaining

1. Perangkat lunak yang dirancang dengan rule-based expert system digunakan untuk menganalisa macam-macam penyakit leukemia dan gejala-gejala leukemia. Sehingga dapat membantu user atau pengguna program untuk mengetahui penyakit leukemia berdasarkan gejalagejala yang diderita.

2. Dengan mengetahui gejala penyakit leukemia yang dialami user maka sistem mampu memberikan solusi dari gejala leukemia tersebut.

3. Perangkat lunak Sistem Pakar mendiagnosa penyakit leukemia diimplementasikan dengan Java Netbeansmenampilkan menu-menu sederhana sehingga dapat digunakan oleh siapapun yang membutuhkannya. baik itu oleh masyarakat umum, pasien karena cara menggunakannya sangat mudah tidak perlu menguasai keahlian khusus tentang komputer.

\section{DAFTAR PUSTAKA}

AdiNugroho. 2002. "Analisis dan perancangan sistem informasi dengan metodologi berorientasi objek", Informatika, Bandung.

Anton, Rina Anggraini, 2008, Sistem Teknologi Voice Over Ip (VOIP).

Arhami, Muhammad. 2004. Konsep Dasar Sistem Pakar. Yogyakarta: Andi Yogyakarta.

Arhami, Muhammad, 2005, Konsep Dasar Sistem Pakar. Penerbit Andi, Yogyakarta

Dharwiyanti,Sri."Pengantar Unified Modelling Language (UML)". Available from Arhami,M.(2005). "Konsep Dasar Sistem Pakar"Yogyakarta, Andi Offset.

Ernita, T, dkk., 2013, Buku Panduan Penulisan Proposal dan Skripsi STTIND Padang.

Grady Booch. 1999. Visual Modeling With Rational Rose 2000 And UML
Geni, Apria, Dina, dkk., 2010, Sistem Pakar untuk Mendiagnosa Penyakit Usus Buntu dengan Metode Backward Chaining. Laporan Kerja Praktek Fakultas Ilmu Komputer Universitas Putra Indonesia "YPTK" Padang, 2010

Giarratano. J, dan Riley. G, (1993) : Expert System, University of Houston, ClearLake and NASA, Johnson Space Center.

Gunawan, B.Y., 2005, Sistem Pakar Berbasis Web untuk Diagnosis Penyakit Tanaman Acacia Spp. Program Studi Ilmu Komputer Sekolah Pascasarjana Universitas Gadjah Mada, Yogyakarta

Hartati, Sri dan Sari Iswanti. 2008. Sistem Pakar dan Pengembangannya. Yogyakarta: Graha Ilmu.

Hm Jogiyanto, Analisis Perancangan Sistem Informasi, Andi Offset, Yogyakarta, 2001.

Kusrini. Menentukan Faktor Kepastian Pengguna dengan Metode Kuntifikasi Pernyataan. Aplikasi Sistem Pakar. ANDI Yogyakarta , 2008

Turban, E., 1995. Decision Support System and Expert Systems. USA: Prentice Hall International Inc.

Marimin.1992.Pengenalan Sistem Pakar. Jakarta : Elex Media Komputindo

Merlina, Nita, M.Kom., \& Rahmat Hidayat, S.Kom. 2012. Perancangan Sistem Pakar. Ghalia Indonesia. Yogyakarta. www.sith.itb.ac.id/profilel/pdf/bisel/leukemia 